\title{
PEMAHAMAN KONSEP BELAJAR UNTUK MENGASAH KECERDASAN MAJEMUK : PENDEKATAN PENELITIAN TINDAKAN
}

\author{
UNDERSTANDING THE CONCEPT OF LEARNING TO EDUCATE THE \\ INTELLIGENCE OF ADMINISTRATION: THE ACTION RESEARCH APPROACH
}

\author{
Oleh: \\ Intan Rahmawati ${ }^{1}$ \\ Yuliezar Perwira Dara ${ }^{2}$ \\ Ulifa Rahma ${ }^{3}$
}

\begin{abstract}
ABSTRAK
Kurang optimalnya pendidikan Sekolah Dasar (SD) dalam mempersiapkan kualitas siswa yang mengoptimalkan kecerdasan majemuk, menjadi masalah utama pada sektor pendidikan. Memberikan pemahaman mengenai konsep belajar yang tepat menjadi kebutuhan dasar untuk mengoptimalkan kecerdasan majemuk siswa. Penelitian ini menggunakan pendekatan action research dengan mencoba melakukan serangkaian kegiatan optimalisasi kecerdasan majemuk siswa SD Nengeri (N) 1 Sumber Bening, Kecamatan Bantur, Kabupaten Malang. Pada kegiatan ini, peneliti terlebih dahulu melakukan pemetaan kecerdasan siswa serta memberikan pemahaman konsep belajar pada orangtua dan guru melalui psikoedukasi. Kegiatan ini menunjukkan bahwa kecenderungan kecerdasan siswa kelas 4,5, dan 6 SD N 1 Sumber Bening terletak pada kecerdasan natural kemudian disusul pada kecerdasan interpersonal. Pada pemetaan ini, tampak sebanyak 12 siswa memiliki kecenderungan pada kecerdasan natural (26\%) sedangkan 11 siswa menunjukkan kecerdasan interpersonal (24\%). Kemudian untuk kecerdasan lain terlihat kecerdasan linguistic (bahasa) sebanyak 1 orang (2\%); kecerdasan logical-mathematical (logika angka) sebanyak 4 orang (9\%); kecerdasan musikal sebanyak 6 orang (13\%); kecerdasan bodily-kinetsthetic (gerak badan) sebanyak 5 orang (11\%); kecerdasan spatial-visual (spasial) sebanyak 1 orang (2\%); dan kecerdasan intrapersonal sebanyak 6 orang (13\%). Hasil lain menunjukkan adanya pemahaman yang meningkat tentang konsep belajar untuk mengasah kecerdasan majemuk siswa.
\end{abstract}

Kata Kunci: Konsep Belajar; Kecerdasan Majemuk; Psikoedukasi

\section{ABSTRACT}

The lack of optimal elementary school education in preparing the quality of students who optimize multiple intelligence is a major problem in the education sector. Providing an understanding of the concept of appropriate learning is a basic need to optimize students multiple intelligence. This study tried to carry out a series of multiple intelligence optimization activities for students of SDN 1 Sumber Bening, Bantur,Malang Regency. In this activity, first, researchers made the map of students multiple intelligence and provide an understanding of the concept of learning to parents and teachers through psychoeducation. This activity shows that the intelligence tendency of students in grade 4, 5, and 6 in SD Sumber Bening in natural intelligence then followed by interpersonal intelligence. In this mapping, it appears that 12 students have a tendency to natural intelligence (26\%) while 11 students show interpersonal intelligence (24\%). Then for

\footnotetext{
${ }^{1}$ Jurusan Psikologi, Fakultas Ilmu Sosial dan Ilmu Politik-Universitas, intanr@ub.ac.id

2 Jurusan Psikologi, Fakultas Ilmu Sosial dan Ilmu Politik, perwiradara@ub.ac.id

${ }^{3}$ Jurusan Psikologi, Fakultas Ilmu Sosial dan Ilmu Politik, ulifa.rahma@ub.ac.id
} 
INTAN RAHMAWATI, YULIEZAR PERWIRA DARA, \& ULIFA

RAHMA, Pemahaman Konsep Belajar untuk Mengasah Kecerdasan Majemuk:

Pendekatan Tindakan

other intelligences there are 1 linguistic (language) intelligence (2\%); logicalmathematical intelligence (logic number) of 4 people (9\%); musical intelligence as many as 6 people (13\%); bodily-kinetsthetic intelligence (gestures) of 5 people (11\%); spatialvisual (spatial) intelligence of 1 person (2\%); and intrapersonal intelligence as many as 6 people (13\%). Other results show an increased understanding of the concept of learning to hone students' multiple intelligences.

Keywords: Learning Concept; Multiple Intelligence; Psychoeducation

\section{PENDAHULUAN}

Secara umum, kendala pada dunia pendidikan dasar untuk dapat menghasilkan lulusan yang berkualitas adalah pelaksanaan kegiatan belajar yang masih tradisional (menekankan kemampuan matematika dan bahasa saja). Hingga saat ini, siswa yang berprestasi cenderung dilihat berdasarkan nilai matematika dan bahasa saja tanpa melihat aspek lainnya.

Piaget (Bredekamp \& Copple, 1999) menjelaskan bahwa anak pada usia 7 hingga 11 tahun, anak-anak berada dalam tahap perkembangan operasional konkret. Tahap ini dicirikan dengan kemampuan bernalar secara logis saat penalasaran tersebut dapat dibayangkan dan diaplikasikan pada hal yang bersifat konkret dan spesifik. Pada tahap ini, anak sangat memerlukan penalaran logika, sehingga sangat baik apabila sekolah dasar dapat memfasilitasi dan melakukan stimulasi pada aspek tersebut. Perkembangan kognitif pada tahap ini tidak hanya dilakukan dengan memberikan stimulasi melalui program akademik saja, melainkan seluruh aspek perkembangan agar mampu menunjang prestasi belajar anak.

Konsep belajar yang masih berpola tradisional ini merupakan tantangan pendidikan nasional dalam melihat potensi lain pada siswa. Mengukur prestasi siswa hanya dengan kemampuan matematika dan bahasa saja belum menunjukkan potensi kecerdasan lain yang dimiliki (Armstrong, 2003). Piaget (Pardjono, 2000) menjelaskan bahwa konsep belajar sebenarnya adalah sebuah proses perubahan yang membangun konsep baru melalui asimilasi dan akomodasi skema yang telah dimiliki. Oleh sebab itu, belajar merupakan proses yang terus menerus dan tidak berkesudahan. Asimilasi merupakan proses kognitif dalam mengintegrasi persepsi, konsep maupun pengalaman baru dalam skema atau pola yang sudah ada dalam pikirannya. Sementara itu, akomodasi merupakan keadaan seseorang membentuk skema baru yang cocok dengan stimulus baru. Pada akomodasi terdapat proses memodifikasi skema yang ada sesuai dengan stimulus yang baru.

Pada konsep belajar, Ausubel (dalam Suparno, 1997) mengemukakan bahwa belajar memiliki konsep konstruktif, yakni menekankan pentingnya siswa mengasosiasikan pengalaman, fenomena, dan fakta baru ke dalam sistem pengertian yang dimiliki. Selain itu, menekankan pentingnya asimilasi pengalaman baru ke dalam konsep atau pengertian yang sudah dimiliki siswa, serta siswa aktif dalam proses belajar. Pelaksanaan konsep belajar konstruktif ini 
dapat dilaksanakan dengan enam aspek utama, yakni situation, grouping, brigde, question, exhibit, dan reflection (Gagnon \& Michelle, 1996). Konsep belajar konstruktif ini akan melibatkan siswa secara aktif dalam proses pembelajaran melalui situasi belajar mengajar yang memungkinkan siswa untuk belajar memecahkan masalah, mengambil keputusan, dan menetapkan tujuan. Pengelompokan terhadap siswa dan materi juga akan memungkinkan siswa untuk mengembangkan makna baru pada saat bertukar pikiran dengan siswa lainnya. Pada aspek membangun bridge, siswa diharapkan juga mampu menguasai materi yang disampaikan. Sementara itu, aspek question berisi ragam pertanyaan yang diharapkan membangkitkan keingintahuan siswa untuk mencoba menemukan jawaban tersebut. Pada aspek exhibit dapat dilakukan dengan kegiatan menjelaskan contoh konkrit suatu penjelasan dan pada aspek terakhir, siswa dapat merefleksikan yang telah dipelajari, yang diketahui, dan yang ingin diketahui.

Menjawab tantangan ini, sumber daya manusia (guru dan orangtua) yang menyertai siswa perlu mengenal kecerdasan majemuk untuk membantu siswa belajar konstruktif sehingga dapat menciptakan produk atau kemampuan dalam menyelesaikan masalah. Kecerdasan majemuk merupakan validasi tertinggi yang menggambarkan bahwa perbedaan individu merupakan faktor penting yang perlu diperhatikan. Penggunaan kecerdasan majemuk dalam dunia pendidikan sangat tergantung pada pengenalan, pengakuan, dan penghargaan terhadap setiap cara siswa dalam belajar, pengenalan materi, dan juga penghargaan pada tiap minat siswa. Jasmine (2007) menyatakan bahwa kecerdasan majemuk tidak saja hanya menunjukkan pengakuan terhadap perbedaan individual, namun juga untuk pengajaran, penilaian, serta menerima sebagai sesuatu yang normal, wajar, menarik, dan berharga.

Kecerdasan majemuk (Gardner, 1993) berkembang dalam delapan kategori. Pertama, kecerdasan bahasa. Pada kecerdasan ini siswa mampu menggunakan kata-kata baik secara lisan maupun tulisan untuk mengekspresikan ide atau gagasan yang dimiliki. Siswa yang memiliki kecerdasan ini akan mampu berbahasa dengan lancar, baik, lengkap, dan mudah untuk mengetahui, mengembangkan dan mempelajari berbagai bahasa dengan mudah. Kedua, adalah kecerdasan matematika. Kecerdasan ini berkaitan dengan kemampuan penggunaan bilangan dan logika secara efektif, peka terhadap pola logika, abstraksi, kategorisasi, dan penghitungan. Ketiga, adalah kecerdasan ruang visual yakni mampu menangkap dunia ruang visual secara tepat dengan mengenal bentuk dan benda, melakukan perubahan bentuk benda dalam pikiran dan menggali perubahan tersebut. Keempat, kecerdasan gerak badan yang merupakan kemampuan untuk secara aktif menggunakan bagian atau seluruh tubuh untuk berkomunikasi dan memecahkan masalah. Kelima, kecerdasan musikal. Pada kecerdasan ini, siswa memiliki kemampuan untuk mengekspresikan, menikmati bentuk music dan suara, peka terhadap ritme, melodi, dan intonasi serta mudah memainkan alat musik, dan mengikuti nada untuk bernyanyi.

Kecerdasan majemuk keenam, adalah kecerdasan interpersonal yang merupakan kemampuan untuk mengerti dan peka terhadap perasaan, motivasi, 
INTAN RAHMAWATI, YULIEZAR PERWIRA DARA, \& ULIFA

RAHMA, Pemahaman Konsep Belajar untuk Mengasah Kecerdasan Majemuk:

Pendekatan Tindakan

ekspresi wajah, suara, dan isyarat dari orang lain. Kemampuan ini akan menunjukkan kemudahan dalam menjalin relasi dan berkomunikasi dengan orang lain. Ketujuh adalah kecerdasan intrapersonal yang merupakan kemampuan untuk mengerti tentang diri sendiri dan mampu bertindak secara adaptif berdasarkan pengenalan diri. Pada kecerdasan ini, siswa mampu mengendalikan emosi sehingga tampak tenang dan dapat berkonsentrasi dengan baik. Kecerdasan kedelapan adalah kecerdasan lingkungan atau natural yang menunjukkan kemampuan mengerti flora dan fauna dengan baik, dapat memahami, menikmati alam, dan menggunakan secara produktif dalam pengetahuan alam.

SD N 01 Sumber Bening merupakan salah satu sekolah dasar di desa Sumber Bening, Kecamatan Bantur, Kabupaten Malang yang belum pernah melakukan pemetaan mengenai kecerdasan siswanya. Pada sisi yang lain, orang tua dan tenaga pendidik SD 1 Sumber Bening, Kec. Bantur, Kab. Malang juga belum pernah mendapatkan sosialisasi mengenai kecerdasan majemuk yang dapat mengoptimalisasi potensi siswa.

Melihat urgensi dan fakta di lapangan tersebut, maka penelitian ini berupaya untuk melakukan pemetaan kecerdasan masjemuk untuk kemudian diberikan pengetahuan mengenai konsep belajar yang dapat mengasah kecerdasan majemuk siswa. Pemberian pengetahuan ini melalui psikoedukasi untuk orangtua dan guru sebagai bentuk optimalisasi peran sekolah dalam menggali potensi siswa.

\section{METODE PENELITIAN}

Penelitian ini merupakan penelitian tindakan (action research) dengan pendekatan kualitatif yang memiliki model siklik dengan proses awal sebagai panduan dalam merumuskan aksi untuk proses berikutnya. Siklus pada penelitian tindakan ini berawal dari diagnosis, planning action, taking action, evaluating action, dan reflection. Seluruh tahapan ini difokuskan pada upaya memecahkan suatu permasalahan dengan pendekatan ilmiah (McNiff \& Whitehead, 2006; Davison , Martinsons, \& Ou, 2012). Siklus penelitian ini dapat terangkum dalam gambar berikut. 


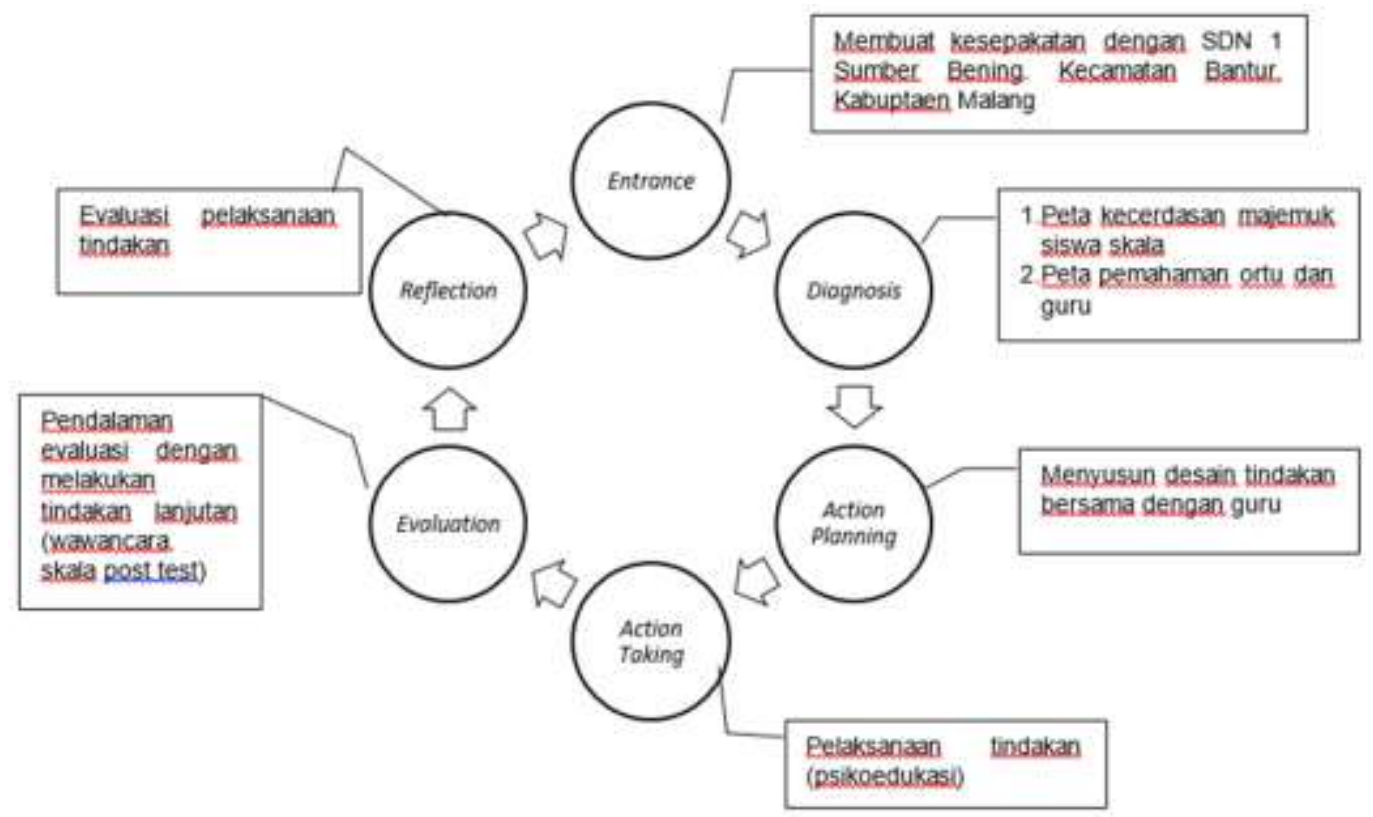

Gambar 1. Siklus penelitian

Pada proses pemetaan yang merupakan diagnosis dalam siklus penelitian ini, peneliti melakukan serangkaian studi pendahuluan untuk memahami problem belajar anak dengan melakukan observasi, wawancara, dan diskusi kelompok terarah pada orangtua. Partisipan dalam penelitian tindakan ini sejumlah 46 siswa dari kelas 4 (16 siswa), kelas 5 (11 siswa), dan kelas 6 (19 siswa). Selain itu, partisipan dalam kegiatan tindakan yang berupa psikoedukasi adalah orangtua dari seluruh siswa yang menjadi partisipan, serta guru sebagai tenaga sumber daya manusia yang menyertai dalam pengoptimalan kecerdasan majemuk siswa. Proses evaluasi pada siklus ini dilakukan dengan penyebaran skala kecerdasan majemuk untuk mengetahui perubahan pemahaman orangtua

\section{HASIL DAN PEMBAHASAN}

Berdasarkan hasil pemetaan diketahui peta kecerdasan majemuk siswa kelas 4,5, dan 6 SD 1 Sumber Bening, Kecamatan Bantur, Kabupaten Malang sebagai berikut.

Tabel 1. Peta Kecerdasan Siswa SD 1 Sumber Bening

\begin{tabular}{ccccccccc}
\hline & \multicolumn{7}{c}{ Kecerdasan } \\
\cline { 2 - 9 } Kls & Interpersonal & Natural & $\begin{array}{l}\text { Logis- } \\
\text { matematis }\end{array}$ & Musik & Spasial & Gerak & Intrapersonal & Linguistik \\
$\mathbf{4}$ & 14,1 & 13,68 & 13,74 & 13,05 & 12,37 & 11,74 & 11,68 & 11,11 \\
$\mathbf{5}$ & 16,0 & 16,64 & 15,36 & 12,45 & 14,73 & 13,54 & 12,18 & 12,73 \\
$\mathbf{6}$ & 15,44 & 15,63 & 13,56 & 14,25 & 14,19 & 13,75 & 13,68 & 13,56 \\
\hline
\end{tabular}


INTAN RAHMAWATI, YULIEZAR PERWIRA DARA, \& ULIFA

RAHMA, Pemahaman Konsep Belajar untuk Mengasah Kecerdasan Majemuk:

Pendekatan Tindakan

Pada pemahaman konsep belajar, orangtua mengeluhkan sulit mengatur waktu belajar bagi anak karena anak lebih banyak menghabiskan waktu untuk bermain. Orangtua menganggap belajar adalah aktivitas mengerjakan soal latihan saja Orangtua sebelumnya mengartikan anak yang cerdas adalah yang dapat mengerjakan pelajaran matematika dengan cepat dan tepat. Setelah diberikan pemahaman melalui psikoedukasi, orangtua memahami seluruh kategori kecerdasan majemuk perlu untuk diasah melalui kegiatan belajar mengajar. Mengoptimalkan kecerdasan majemuk ini dengan melatih bakat yang telah dimiliki dan memberikan stimulus pengembangan bakat dalam materi pelajaran.

Peta pemahaman kecerdasan majemuk pada orangtua yang digali dari pertanyaan terbuka dapat tergambarkan sebagai berikut.

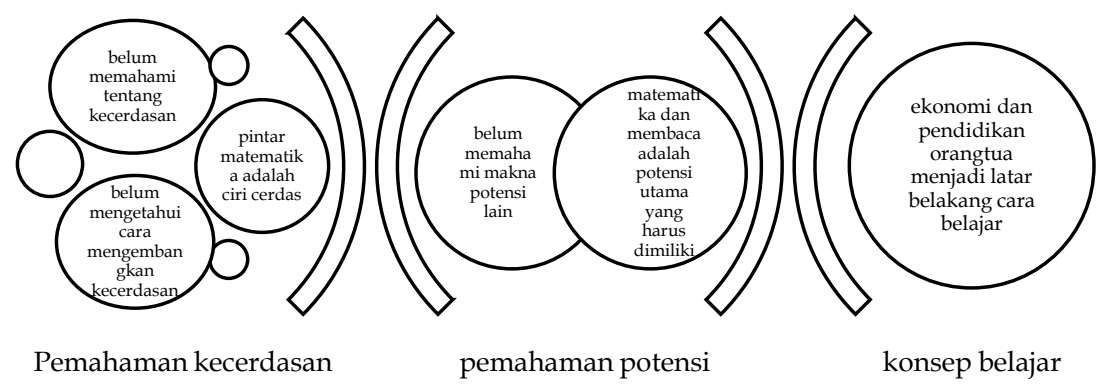

Gambar 1. Peta Pemahaman Orangtua

Berdasarkan hasil tersebut di atas didapatkan bahwa untuk dapat mengembangkan kecerdasan majemuk diperlukan pengetahuan dasar bagi guru dan orangtua sebagai landasan dalam membuat program-progam untuk mengoptimalkan kecerdasan majemuk anak. Khani (2014) mengatakan bahwa dalam setting pendidikan, kualitas guru dalam berkomunikasi memberikan pengajaran akan memengaruhi intelegensi siswa, sehingga perkembangan siswa akan berjalan lebih optimal. Selain itu, siswa yang didorong lebih untuk melakukan tugas kognitif yang kompleks akan meningkat secara substansial dalam pemahaman, disiplin dan siap berkompetensi.

Kecerdasan majemukjuga dapat diarahkan dalam kegiatan pengembangan proses pembelajaran, karena strategi dalam stimulasi kecerdasan berefek langsung pada perkembangan anak. Masing-masing aspek perkembangan anak akan saling memengaruhi. Bila salah-satu aspek terhambat maka aspek lain akan terhambat pula. Sebagai contoh, keterlambatan pada perkembangan fisik akan berpengaruh pada perkembangan emosi, kepribadian, kreativitas, dan sosial anak. Oleh karena itu, pendidik dan orangtua harus menaruh perhatian pada semua aspek perkembangan anak. Pada pendidik turut bertanggung jawab terhadap perkembangan anak didiknya. Sebagai wujud tanggung jawabnya, pendidik hendaknya menyusun rencana dan melaksanakan kegiatan pengembangan anak. 
Pada penyusunan rencana kegiatan tersebut, pendidik hendaknya mengimplementasikan konsep-konsep kecerdasan majemuk (Amstrong, 2008). Setiap guru/pendidik perlu untuk mengintegrasikan keterampilan dan subketerampilan untuk mencapai tujuan yang lebih besar. Guru/pendidik dapat menyediakan berbagai fasilitas dan aktivitas yang menarik sehingga anak dapat melaksanakan berbagai kegiatan yang terintegrasi dalam satu proyek atau kegiatan.

Menurut Bredekamp (1993) tujuan setiap kegiatan memungkinkan anak melakukan eksplorasi, dan memecahkan masalah secara bermakna. Kegiatan pengembangan ditujukan untuk mendorong anak melaksanakan proyek atau permainan mulai dari belajar membuat rencana, menuliskan rencana, dan menerapkan (menduga, mengobservasi, melakukan percobaan, mencocokkan penemuan dengan pengalaman). Selain itu, guru/pendidik perlu juga melakukan hal-hal berikut (a) Mengintegrasikan matematika dengan sains dan kaji sosial; (b) Mengintegrasikan kaji sosial dengan bahasa dan seni; (c) Mengintegrasikan kesehatan dan keselamatan dengan kebiasaan sehari-hari; (d) Mengintegrasikan seni musik, gerak, drama, dan tari; dan (e) Mengintegrasikan aktivitas.

Hasil data yang didapatkan dalam penelitian ini terlihat bahwa lingkungan berperan dalam pengoptimalan kecerdasan majemuk anak. Peran lingkungan ini terdiri dari (a) Akses ke sumber daya atau mentor bakat; (b) historis kultural; (c) faktor geografis; dan (d) situasional. Kecerdasan natural yang mendominasi siswa SD 01 Sumber Bening menunjukkan bahwa keterampilan siswa dapat dipengaruhi oleh faktor lingkungan eksternal. Kondisi lingkungan sekitar Desa Sumber Bening merupakan kawasan yang masih asri dengan lingkungan alamnya dengan dominasi perkebunan dan hutan, sehingga tidak mengherankan jika dominasi kecerdasan yang ditunjukan siswa merupakan kecerdasan natural.

Gardner (1993) menyebutkan bahwa kecerdasan natural merupakan kecerdasan yang ditandai dengan keahlian membedakan anggota-anggota suatu spesies, mengenali eksistensi spesies lain, dan memetakan hubungan. antara beberapa spesies, baik secara formal maupun informal. Siswa yang optimal kecerdasan naturalisnya cenderung menyukai dan efektif dalam menganalisis persamaan dan perbedaan, menyukai tumbuhan dan hewan, mengklasifikasi flora dan fauna, mengoleksi flora dan fauna, menemukan pola dalam alam, mengidentifikasi pola dalam alam, melihat sesuatu dalam alam secara detil, meramal cuaca, menjaga lingkungan, mengenali berbagai spesies, dan memahami ketergantungan pada lingkungan. Siswa tampak tidak takut memegang-megang serangga dan berada di dekat binatang. Sebagian besar anak berusaha memenuhi rasa ingin tahunya dengan cara bereksplorasi di alam terbuka, mereka mencari cacing di sampah, membongkar sarang semut, menelusuri sungai.

Pengoptimalan kecerdasan majemuk juga dapat dilihat dari beberapa faktor. Pertama adalah faktor biologis. Faktor yang termasuk di dalamnya adalah keturunan atau genetis dan luka atau cedera otak sebelum, selama, dan setelah kelahiran. Kedua adalah sejarah hidup pribadi. Pada faktor ini dapat berupa pengalaman dengan orangtua, guru, teman sebaya, kawan-kawan, dan orang lain, 
INTAN RAHMAWATI, YULIEZAR PERWIRA DARA, \& ULIFA

RAHMA, Pemahaman Konsep Belajar untuk Mengasah Kecerdasan Majemuk:

Pendekatan Tindakan

baik yang membangkitkan maupun yang menghambat perkembangan kecerdasan. Ketiga adalah latar belakang kultural dan historis termasuk waktu dan tempat individu dilahirkan dan dibesarkan serta sifat dan kondisi perkembangan historis atau kultural ditempat-tempat lain (Mehr, 2006).

Selain ketiga faktor utama tersebut di atas, Mehr (2006) menjelaskan terdapat faktor pendorong dan penghambat kecerdasan majemuk. Faktor tersebut adalah crystallizing dan paralyzing experiences yang merupakan dua proses kunci dalam perkembangan kecerdasan. Faktor ini berupa titik balik dalam perkembangan bakat dan kemampuan orang. Seringkali titik balik itu terjadi pada awal masa kanak-kanak meskipun dapat terjadi sepanjang hidup.

Selain itu, Gardner dan Davis (2013) juga membuka opsi melihat pandangan yang berbeda yang melihat bahwa media digital adalah alat-alat spektrum intelektual yang jauh lebih besar. Sehingga memungkinkan terbukannya banyak bentuk ekspresi dan pemahaman seseorang, memberikan ekspresi tambahan bagi semua anak khususnya bagi mereka yang memiliki kekuatan selain pada area bahasa dan logika saja, hal tersebut memungkinkan sekali untuk menggunakan pendekatan dengan mengaplikasikan teori kecerdasan majemuk.

Orangtua dan guru dapat membawa anak-anak mereka ke alam terbuka, menyediakan materi-materi yang tepat untuk mempertimbangkan kecerdasan naturalis, seperti membiasakan menyiram tanaman, menciptakan permainan yang berkaitan dengan unsur-unsur alam, seperti membandingkan berbagai bentuk daun dan bunga, mengamati perbedaan tekstur pasir, tanah, dan kerikil, mengoleksi biji-bijian, dan menirukan karakteristik binatang tertentu. Sebaiknya, buku-buku dan VCD yang memuat seluk-beluk hewan, alam, dan tumbuhan dengan gambar-gambar yang bagus dan menarik perlu di pajang di depan anak. Dalam kadar kecil, kecerdasan naturalis dapat diwujudkan dalam kegiatan investigasi, eksperimen, menemukan elemen, fenomena alam, pola cuaca, kondisi yang mengubah karakteristik sebuah benda, misalnya es mencair ketika terkena panas matahari. Amini, Tamanayefar, \& Amini (2009) menjelaskan, kecerdasan naturalis memiliki peran yang besar dalam kehidupan. Pengetahuan siswa mengenai alam, hewan, dan tumbuh-tumbuhan dapat mengantarkan mereka ke berbagai profesi strategis, seperti dokter hewan, insinyur pertanian, perkebunan, kehutanan, kelautan, ahli farmasi, ahli geodesi, geografi, dan ahli lingkungan.

Selanjutnya, kecerdasan yang mendominasi siswa SD N 1Sumber Bening adalah kecerdasan interpersonal. Kecerdasan ini ditandai dengan kemampuan mencerna dan merespons secara tepat suasana hati, temperamen, motivasi, dan keinginan orang lain. Seseorang yang optimal dalam kecerdasan ini cenderung menyukai dan efektif dalam hal mengasuh dan mendidik orang lain, berkomunikasi, berinteraksi, berempati dan bersimpati, memimpin dan mengorganisasikan kelompok, berteman, menyelesaikan dan menjadi mediator konflik, menghormati pendapat dan hak orang lain (Gradner, 1993). 
Cara belajar terbaik bagi anak yang cerdas interpersonal adalah melalui interaksi dengan orang lain. Anak dengan kecerdasan ini akan tampak sebagai individu yang manis, baik hati, dan suka perdamaian, oleh karena itu, mereka disukai banyak orang. Untuk mengembangkan kecerdasan ini, guru dan orangtua perlu memberikan tugas-tugas menarik yang harus diselesaikan anak secara berpasangan dan berkelompok. Kegiatan bermain bersama di bawah pengawasan pendidik sangat disarankan (Gradner, 1993).

\section{KESIMPULAN}

Kecenderungan kecerdasan siswa kelas 4, 5, dan 6 SD Negeri Sumber Bening terlihat pada kecerdasan natural. Kemudian pada urutan kedua terdapat kecerdasan interpersonal. Sebanyak 12 siswa memiliki kecenderungan pada kecerdasan natural (26\%) sedangkan 11 siswa menunjukkan kecerdasan interpersonal (24\%). Untuk kecerdasan majemuk lainnya, tampak kecerdasan linguistic (bahasa) sebanyak 1 orang (2\%), kecerdasan logical-mathematical (logika angka) sebanyak 4 orang (9\%), kecerdasan musical (musik) sebanyak 6 orang (13\%), kecerdasan bodily-kinetsthetic (gerak) sebanyak 5 orang (11\%), kecerdasan spatial-visual sebanyak 1 orang $(2 \%)$, dan kecerdasan intrapersonal sebanyak 6 orang $(13 \%)$.

Kegiatan psikoedukasi yang dilaksanakan menunjukkan dapat meningkatkan pemahaman orangtua terhadap pemahaman mengenai kecerdasan majemuk anak. Psikoedukasi ini diharapkan dapat memberikan wawasan pada orangtua mengenai konsep belajar yang tepat agar dapat digunakan sesuai dengan kecerdasan majemuk yang dimiliki.

\section{DAFTAR PUSTAKA}

Amini, M., Tamanayefar, M., \& Amini, S. (2009). Multiple Intelligence Theory and Its Implications in Designing Experiences and Learning Opportunities. Journal of New Thoughts on Education, 5(4), 91-106.

Armstrong, T. (2003). Sekolah Para Juara. (Y. Murtanto, Trans.) Bandung: Kaifa.

Bredekamp, S., \& Copple, C. (1999). Developmentally Appropriate Practice in Early Childhood Programs. Washington DC: National Association for the Education of Young Children.

Davison , R. M., Martinsons, M. G., \& Ou, C. X. (2012). The Roles of Theory in Canonical Action Research. 36(3), 763-786.

Gagnon, G. J., \& Michelle, C. (1996). Teachers Perspectives an a Constructivist Learning Design. Retrieved from http://www.prainbow.com/cld/clds.html. 
INTAN RAHMAWATI, YULIEZAR PERWIRA DARA, \& ULIFA

RAHMA, Pemahaman Konsep Belajar untuk Mengasah Kecerdasan Majemuk:

Pendekatan Tindakan

Gardner, H. (1993). Multiple Intelligences : The Theory in Practice A Reader. New York: Basic Books.

Gardner, H., \& Davis, K. (2013). The app generation: How today's youth navigate identity, intimacy, and imagination in a digital world. United States: Yale University Press.

Jasmine, J. (2007). Panduan Praktis Mengajar Berbasis Kecerdasan Majemuk. Bandung: Nuansa .

Khani, R. S. (2014). Build and Standardize Gardner Multiple Intelligence Test. Journal of Educational Measurment, 5(18), 179-205.

McNiff, J. E., \& Whitehead, J. (2006). All you need to know about action research. London: Sage.

Mehr, M. (2006). Multiple Intelligence Theory and Its Implications for Curriculum and Education. Journal of Education, 22(4), 7-31.

Pardjono. (2000). Konsepsi Guru tentang Belajar dan Mengajar dalam Perspektif Belajar Aktif. Jurnal Psikologi, 2, 73-83.

Suparno, P. (1997). Filsafat Konstruktivisme dalam Pendidikan. Yogyakarta: Penerbit Kanisius 